\title{
Guidance and Counseling in Nigerian Secondary Schools: The Role of ICT
}

\author{
Oye N. D. \\ Department of Information Systems, Universiti Teknologi Malaysia \\ oyenath@yahoo.co.uk \\ Obi M. C. \\ Department of Information Systems, Universiti Teknologi Malaysia \\ monicaobi@yahoo.com \\ Mohd T. N. \\ Department of Information Systems, Universiti Teknologi Malaysia \\ mtajudin@utm.my \\ Bernice, A. \\ Gwadabawa GDSS, Yola- Nigeria. \\ vivnat@yahoo.co.uk
}

\begin{abstract}
The importance of guidance and counseling programme in secondary schools, include bringing to the students an increased understanding of the educational, vocational and social information needed to make wise choices. In our society there are many influencing forces responsible for the gradual recognition of formal guidance to young people in various educational levels. This review paper focuses on the role of ICT on guidance and counseling in secondary schools. Counseling is a form of education, which the students receive from their counselors. The essence of incorporating guidance and counseling into the school system was to eliminate overwhelming ignorance of many young people on their choices of career prospects and personality maladjustment among school children. The role of ICT in guidance can be seen in three ways: as a tool, as an alternative, or as an agent of change. The growth of websites and help lines as forms of technically mediated service delivery means that the potential of ICT as a change agent is now greater than ever before. The telephone, websites and e-mail, alongside face-to-face facilities, could be alternative services; or they could be portals into a wide, flexible and well-harmonized network of services. The paper recommends that principals should make provision for guidance and counseling on the school time table. Most importantly secondary school ICT adoption should be encouraged by the ministry of education.
\end{abstract}

Index Term - Counseling, Guidance, ICT, Career information, Principals, PTA

\section{INTRODUCTION}

Education is said to be an accumulated experience that has a determinant effect on human character and mind. As a process, through which societal values, norms, principles, ethos, and skills can adequately be conveyed. Individuals need education in order to acquire this accumulated knowledge. The educational system in Nigeria is not far from the technical aspect of education in that it is all involving as a process of transmitting the societal norms and values toward the development of the nation. An overview of the colonial educational system provided, revealed gross inadequacy and unsatisfactory to the educational ingenuity, yearnings and aspirations of the nation. Thus many scholars opined that this formal educations was "parochial, elitist, regurgitate and irresponsive to the need and aspirations of the Nigerian society [1]. In view of these, an effort to put quality into the Nigerian Education resulted in instituting a well define educational system that will be instrumental in affecting national development. It is believed that "education goals in terms of its relevance to the need of the individual as well as in terms of the kind of society desired in relation to the environment and realities of the modern world and rapid social changes should be clearly set out (National Policy on Education, 2004). The bid to meet the nation's educational goals and aspiration brought about the 6-3-34 system of education. It was designed to restructure and inject functionality into the nations' school system. The 6-3-3-4 system of education was seen as a creditable programme able to bring about effective changes in the direction of technological development in a nation.

The essence of incorporating guidance and counseling into the school system was to eliminate overwhelming ignorance of many young people on their choices of career prospects and personality maladjustment among school children. Based on these and more, career officers and counselors were appointed to take the responsibilities in sensitizing students on the needs for effective career choice. Following the tremendous benefits of the first recipients of guidance and counseling in 1959, a group of 
untrained counselors were inaugurated in 1967 by the Reverend Sisters from St Theresa's College Oke-Ado who were the first pioneers of this body. Although these were untrained counselors but their efforts brought remarkable development in guidance and counseling in Nigeria. With more emphasis placed on guidance and counseling as far back as 1959, 1962, 1963 and 1967 respectively, the peak of getting aware of counseling profession in Nigeria was on $11^{\text {th }}$ of November, 1976 following the formal launching of the body of counselors known as Counseling Association of Nigeria (CAN), with Professor Olu Makinde as the first President. In 1977, the association became affiliated to the American Personnel and Guidance Association (APGA) with Professor Ibrahim I. Kolo from Ahmadu Bello University as the current president.

\section{HISTORICAL B ACKGROUND}

In Nigeria, the organized guidance started in 1959 at St. Theresa's College, Oke Ado in Ibadan by some Reverend Sisters, out of concern for the products of their school. These Reverend Sisters were aware of the importance of guidance and counseling services in creating job awareness to their out-going students. They invited some resource people to talk to their final year students on the type of career they may engage in as they enter into the world of works. A total of 54 out of the 60 students benefited from the resource personnel advice and were placed in various jobs. The innovation was highly welcomed by the society because in later years this group of people, though not trained counselors, organized career talks, seminars and workshops for the class five students. Afterwards, the vocational guidance services spread to other public secondary schools outsides Ibadan and across the entire Nigeria. Officials from the ministry of education became interested in these organized services that this group of "career advisers" were invited to provide career talks and workshop for teachers and career masters. Later, the career advisers became a national issue. As to make the Nigerian youth to meet up with the challenges of the global trend in technological advancement and by acquiring the relevant skills needed through the assistances from career counselors in school. Guidance and counseling services has become an integral and essential component of Nigerian educational process for all students as they progress through the educational system. According to [2], the aims of school guidance and counseling services, which are base on a developmental hierarchy, are to provide student, with opportunities to:

i. Develop knowledge and appreciation of themselves and others.

ii. Develop relationship skills, ethical standards and a sense of responsibilities.

iii. Acquire skills and attitude necessary to develop educational goals which are suited to their needs, interest and abilities, and iv. Acquire information that would enable them to make decisions about life and career opportunities

Today, the services has gained prominence in the Nigerian educational system and many are becoming interested in counseling the youths especially students in making wise educational, vocational and social decisions. Counseling Service is one of the recent disciplines introduced into Nigerian Educational system. With the current trends in technological development and globalization, it has become imperative to refocus counseling and widen its scope to meet with the challenges of the modern society especially in Nigerian secondary schools. Counseling, according to [3] is an interpersonal relationship in which one person attempts to help another person to understand and cope with his problems in the area of education, vocation and family relationship.

To ensure that this discipline, counseling wears a national outlook, the National Policy on Education (2004) made it clear that counseling services should be rendered to students in schools. The aforementioned policy document noted that "in view of the apparent ignorance of many young people about career prospects and in view of personality maladjustment among school children, career officers and counselors will be appointed in post primary institutions (Federal Republic of Nigeria, 1981, p43). The above citation gives an idea that all students in the school system should benefit from counseling services. The counseling services became widely recognized as an important aspect of educational services. It was to fulfill the Nigeria government policy and as a way of implementing the policy statement, professional counselors are posted to virtually all the post-primary schools in Nigeria. The policy provision has been encouraging but appears to run short of many processes as well as the problem of implementation. The guidance counselor are expected to render counseling services which according to [4] and [5] include counseling, orientation, information appraisal, placement, referral, fellowship and evaluation. The services are not only to ensure quality in education, but also to help individuals acquire the knowledge, skills, and experience necessary to identify opinions, explore alternatives and succeed in life. No doubt [6] noted that when counselors perform their expected duties in the school setting, then the students will be satisfied as their different academic, vocational, social and personal life aspirations are fulfilled.

\section{CAREER COUNSELING}

Career counseling is very fundamental to students' successful and meaningful living. Every student desire to be identified with a good profession, but this could only be achieved through effective counseling on the choices of career to maximize their potential. Career, though crucial to mankind, occupies almost all entire human life. This is due to the fact that career contribute enormously to all human activities, building individuals 
high self esteem, satisfaction and adjusting to healthy life. It equally assists students to discover their innate potentials and acquire the needed knowledge for building lifelong profession. The word "career" refers to the activities and position involved in vocation, occupation, and jobs as well as to related activities associated with an individual's life time of work [7]. In view of this, adequate utilization of career counseling is required in public secondary schools in Nigeria if the nation's goals are to be attained. According to BAC [8], the term counseling includes work with individuals and with relationships which may be developmental, crisis support, psychotherapeutic, guiding or problem solving. Furthermore, counseling task also involve giving the client an opportunity to explore, discover and clarify ways of living more satisfying and resourcefully as cited in [9].

Akinboye [10] observed that a good number of adolescent and youths in many Nigerian secondary schools have incongruent patterns between their aspirations and subject combination for the school certificate examination. The implication is that most Nigerian youths today engage in occupations not on the basis of "reasonable" choice but on the basis of fate. Case of maladaptive behaviors like violation of school rule and regulation, bullying, truancy, drug abuse, alcohol addition, sexual abuse, rape is on the increase among our school adolescents. Ofordile [11] noted that managing and modifying adolescent maladaptive behavior is still a big challenge facing teachers, student caregivers and the society at large. Students have variety of interest and abilities. This makes it difficult for them to choose a career. In vocational counseling, students should be provided with detailed up- to-date useful information about different careers. The information should be centred on careful planning for a career, getting and retaining the career and adjusting effectively to it. The reason for all these is to let the students consider the various areas in harmony with their potentials and consequently choose the best career [12].

\section{PROBLEMS AFFECTING GUIDANCE AND COUNSELING IN NIGERIAN SECONDARY SCHOOLS}

One begins to question if counseling services are really planned and implemented properly in Nigeria Secondary schools.

The great importance and significance attached to guidance and counseling programme in our educational system makes it necessary for an effective guidance and counseling services in our present secondary schools. This not withstanding however, is likely to face a lot of problems in term of implementation or providing the guidance and counseling masters opportunity to function properly in the school system. The 6-3-3-4 system is generally geared towards harmonizing the society with its technological needs as it attempt to develop the society as the need arises. The problem of inferiority complex, personal confidence, self motivation and inter-personal relationship lead to building of fellow students, this at times leads to truancy in the school. Also some students' do not have self confidence in terms of keeping themselves and do not want help from other people. The problems which manifest themselves in the social and emotional needs of the students which affect students learning conditions are as follows:

- Drug Addition: This is a major problem teachers, parent's school administrations and counselors find hard to cope with and resolving it, for it is usually not easy to get rid of this habit formation when students deviates from counselor's advice.

- The Parent Teacher Association (PTA): This association provides room for dialogue between the teachers and the parents. This can be used as a yardstick that measures the progress of guidance and counseling programme in the state, but lack of such association has been posing threat to the guidance and counseling programme in schools in places where the association is established, parents tends to neglect the attendance of such meeting whenever they are invited, as such they cannot understand the problems of their children as well as their achievements in schools.

- The influence of peer groups: The influence of peer grouped may hinder the progress of guidance and counseling programme among students where the child has been influenced by his friends to make choices of subjects and careers selection based on the interest of his peers. Being his/her friends they may decide to choose the same subject not necessarily considering their interest and capabilities.

- Inadequacy of Guidance Counselor in Secondary Schools: In some schools one may find that there is only one or no counselor handling the guidance and counseling programme and one person cannot effectively perform these functions satisfactorily due to the work load, while in other schools career masters are asked to carry them out.

\section{THE ROLES OF PRINCIPALS AND TEACHERS IN THE GUIDANCE AND COUNSELING PROGRAMME IN SECONDARY SCHOOLS.}

Carew [13] enumerated the role of principals in the provision of guidance and counseling services among which are:-

i. To encourage board participation.

ii. Arrange for guidance activities in the time table.

iii. Recommended competent individuals for in service training in guidance and counseling.

iv. Commend teachers and careers masters, and encourage them in their efforts 
v. Establish the procedure for the student referrals.

vi. Provide dynamic stimulation and leadership.

vii. Provide for expenditure in the budget

Teachers can also help since they are in a better position to observe their students frequently in a variety of situations than the counselor. In the vote of the teachers, it is extensively noted that teachers are not meant to take over the guidance and counseling responsibilities of the counselor because they lack professional training. They further added that school administrators should recommend only graduates of education that offered the course in guidance and counseling and appoint them to serve as career masters.

\subsection{The Roles of Guidance Counselors in Secondary Schools}

In any school setting the roles of the guidance counselor include the following:-

- Taking charge of establishing school guidance programme.

- Coordinating the guidance programme in schools

- Define objectives of the school guidance programme for the benefit of the principals, teachers parents and the students.

- Helping to disseminate career information of the students

- Playing major role in the identification of the guidance needs of the students.

- Supervising the building and maintenance of students' cumulative records in schools.

- Providing relevant data for the placement of students in the transition from junior to senior secondary schools.

- Assisting parents in relating student's interest, attitudes and abilities to current future educational, occupational opportunities and requirement.

- Providing counseling service to the students regarding their educational, vocational and personal social concern.

- Assisting students and parents to understand procedures for applying to higher institutions and for financing student' education.

- Functioning as a resource person to teach in exhibited classroom.

\subsection{The Importance of Guidance and Counseling in our Schools}

The importance of guidance and counseling programme include bringing to the students an increased understanding of the educational, vocational and social information needed to make wise choices. Ipage, [14]
Opined that guidance within the Nigeria culture complies a quesi-parental style of steering the child towards behaviors or decisions deemed to be his good. Olayinka [15] is of the opinion that guidance is a programme that provides service to individual students based upon their needs and understanding of their immediate environment factor have on the students and the unique features of each school. Guidance and counseling can also be as the process and techniques used by a counselor to assist individual to cope with the problems in the areas of his/her life, so that he/she can become useful and contribute to the society in which he lives. One can assert that guidance and counseling is a process developmental in natures by which an individual is assisted to understand, accept and utilize his/her abilities aptitudes interest and attitudinal patterns in relation to his/her aspiration.

Prior to 1937 very little attention was given by the government and education to formal guidance of young people in educational settings. Due to the rapid development the country is undergoing, it calls for technological advancement hence guidance and counseling needs to be adopted to the changes faced by the new system of education (6-3-3-4) system which is a two tier secondary schools system of six years duration and it is divided into two stages of Junior and Senior secondary each being a three (3) years duration. The Federal Ministry of Education initiated the establishment of guidance and counseling in all secondary schools as a result of the apparent prospects and in view of personality mal-adjustment among the school children.

\section{THE ROLE OF ICT AND GUIDANCE AND COUNSELING}

The knowledge of ICT usage improves human capacity in every fields of human endeavor such as business transactions, industrial operations, educational programmes and activities in all aspects of life in general. According to [16]6), ICT is a revolution that involves the use of computers, internet and other telecommunication technology in every aspects of human endeavor. Ozoji in Jimoh [17], define ICT as the handling and processing of information (texts, images, instructions, etc) for use, by means of electronic and communication devices such as computer, cameras, telephone. Ofodu [18] also refers to ICT as electronic or computerized devices, assisted by human and interactive materials that can be used for a wide range of teaching and learning as well as for personal use. From these definitions, ICT could therefore be defined as processing and sharing of information using all kinds of electronic devices, an umbrella that includes all technologies for the manipulation and communication of information.

The role of ICT in guidance can be seen in three ways: as a tool, as an alternative, or as an agent of change. The growth of websites and help lines as forms of technically mediated service delivery means that the potential of ICT as a change agent is now greater than 
ever before. The telephone, websites and e-mail, alongside face-to-face facilities, could be alternative services; or they could be portals into a wide, flexible and well-harmonized network of services. Public policy may support or impede such harmonization. The potential roles of public policy in relation to ICT-based guidance and information provision include funding such provision as part of their general funding for guidance and information services.

In these various respects, ICT has the potential to significantly increase access to guidance services, freeing it from constraints of time and space. At the same time, however, there may be restrictions on access to the ICT resources themselves. There is widespread concern that the growth of the Internet is exacerbating inequalities between the information-rich and the information-poor: between industrialized and developing countries; between the rich and poor within each nation; and between those who are technically literate and those who are technically inept (OECD, 2000). In the USA, for example, households with incomes of \$75,000 and higher are twenty times more likely to have access to the Internet than those at the lowest income levels, and more than nine times as likely to have a computer at home [21]. Growing access to the Internet through the television and telephone is likely to reduce these gaps; libraries and other public information points can also have an important role to play. For the present, though, the gaps remain substantial.

Studies carried out on secondary school students ICT adoption, show students ICT compliance to be below expectation [19], [20] and [21]. While describing Nigeria's position in global technology arena they noted that there is a gap between average Nigerian student's knowledge in computer skills and the computer skill of other students from other countries around the world. Tookiji [22] emphasized that these students need counseling to improve ICT skills before graduation. Counseling is a form of education, which the students receive from their counselors. Palmer [23] states that counseling is an educational process used in solving problems of the learner. Research findings from [24] and [25] have reported significant positive impact of ICT on counseling. It has generated high levels of enthusiasm and commitment during the counseling process as well as increased reasoning ability of learners, increased attention and concentration [26] and [24]. Anyamene, Nwokolo and Anyachebelu [27] noted that the array of information provided through counseling would help tremendously in production of professionally competent graduates.

\subsection{Roles of integrated websites}

Offer \& Sampson [28] suggest that career centers' websites can have at least five different purposes. One is as a funnel into their own existing off-line services, aiming to maximize take-up of these services. The second is to act as a diversion, seeking to take the pressure away from these off-line services by diverting users to other, usually web-based resources where their needs can be met. The third is an enhancement of such diversion, seeking to deliver on-line guidance within the site itself. The final two add further enhancements: providing a forum for putting users in contact with others facing similar issues to their own, or with people who may offer help in relation to these issues (e.g. potential career mentors); and providing a source of distance learning programmes in career management skills and related areas [29]..

\subsection{Telephone help lines}

Alongside websites, there has been growing interest in the use of telephone help lines in delivering career information and guidance services. The largest telephone helpline service in this field is the Learn direct service in the UK, which was launched in February 1998 and by the end of 2000 had responded to 2.4 million calls. Other more limited help lines have been launched in other countries, including Canada and New Zealand. A comparative analysis of these help lines indicates that some have been promoted essentially as information services; others as career counseling services. Some are focused primarily on learning or on work; others on career, embracing the two. Some are aimed at young people or adults; others are all-age. Some are separate services based on call centers; others are integrated in various ways into more broadly-based services [30].

The provision of ICT facilities in the resource centers presupposes that counselors and students can use them to improve awareness, adjustment and learning. Shiran [31] has opined that investment in ICT facility will help in counseling and other support services necessary for effective delivery of an ICT-based curriculum should be utmost in government priorities. Globalization and information revolution is increasingly changing the learning process in higher education in Europe and America. Globalization has challenged higher institutions in Nigeria and in particular South East Universities to face new type of learning involving the use of ICT facilities to improve counseling. It has been observed that there is a lack of ICT infrastructure in Nigerian Secondary Schools. It is recommended that attention must be given to the availability of ICT facilities in schools. The availability of Internet services at school will help the counselors and students.

One of the areas in the various services being provided by the school is guidance services or the school counseling services. Through the implementation of the school guidance program various goals and objectives of developing and honing young children to become good and productive citizens of the country could be attained. Through the efficient and effective use of ICT, school counselors are in a better position to provide administrators, teachers, parents, and students the appropriate timely information needed to help all students to set ambitious goals and to realize their goals. The benefits of using ICT in school counseling are so 
great that there is no need for more justification as to why there is an urgent need to undertake our study on integrating ICT in school counseling for the basic education. Martin [32] describes the school counselor of the future as one who will be prepared in a pre-service program to possess pro-active, socially critical behavior and skills needed to strategically plan to challenge the status quo in systems where inequities impede students' academic success. Moreover, Offer \& Watts [29] presents the current use of ICT in relation to relevant forms of personal information, advice, and guidance leading to personal development for young people aged 13 to 19 .

\section{GUIDANCE AND COUNSELING CHALLENGES}

Having presented the duties of the guidance counseling in our schools the big question now is how sincere are the guidance counselors in giving free hand to carry out their duties. A lot of studies have been carried out on the awareness of school principals; teachers and parents on the importance of the counselors and the following observation were noted. In the study on principal's awareness of the importance of guidance, some researchers asserted that some principals have false impression that a school can function effectively and profitably without a guidance counselor. Also in the study of teacher awareness of the importance of guidance, some teachers see the guidance counselors posted to their schools only to engage in complains that there are not required facilities, such as conducive counseling office, psychological and non psychological test, inadequate fund, tape records etc, to start an effective counseling.

In the studies of parents' awareness on the importance of guidance counselor, [6] observed that most parents are only concerned with the principal of the schools any time they bring problems about their children; they prefer to go to the principal than to the guidance counselors. In the new national policy of education (6-3-3-4) the demand for guidance and counseling is apparently made clear, and from the research carried out by individuals above the principals, teachers and parents have wrong awareness of the importance of guidance and counseling programme.

The paper is of the view that majority of the teachers have no regards for guidance and counseling activities in schools. The school time-table does not make provisions for guidance and counseling activities. In other words, school activities in whole terms are design without giving specific period of time for students to have any form of formal guidance and counseling encounters with professional counselor's or selected teachers. The government does not provide adequate support for the promotion of guidance and counseling activities in schools. Therefore there is need for parents of pupils/students in schools to actively participate in the promotion of guidance and counseling activities in schools.
Counseling is a form of education, which the students receive from their counselors. In the new national policy of education (6-3-3-4) the demand for guidance and counseling is apparently made clear. There was agreement also, with a very negligible deviation that the school time-table does not make provisions for guidance and counseling activities. The essence of incorporating guidance and counseling into the school system was to eliminate overwhelming ignorance of many young people on their choices of career prospects and personality maladjustment among school children. The role of ICT in guidance can be seen in three ways: as a tool, as an alternative, or as an agent of change. The growth of websites and help lines as forms of technically mediated service delivery means that the potential of ICT as a change agent is now greater than ever before. The telephone, websites and e-mail, alongside face-to-face facilities, could be alternative services; or they could be portals into a wide, flexible and well-harmonized network of services. The importance of guidance and counseling programme in secondary schools, include bringing to the students an increased understanding of the educational, vocational and social information needed to make wise choices. In our society there are many influencing force responsible for the gradual recognition of formal guidance to young people in various educational levels. This review paper focuses on the role of ICT on guidance and counseling in secondary schools. However principals have false impression that a school can function effectively and profitably without a guidance counselor. The paper recommends that principals should make provision for guidance and counseling on the school time table. Most importantly secondary school ICT adoption should be encouraged by the ministry of education.

\section{ACKNOWLEDGMENT}

The authors would like to acknowledge all the authors of articles cited in this paper. In addition, the authors gratefully acknowledge UTM, Research Universiti Teknologi Malaysia for their support and encouragement.

\section{REFERENCE}

[1] Uwaifo, V. O. \& Uddin, P. S. O. (2009). Transition from the 6-3-3-4 to the 9-3-4 System of Education in Nigeria: An Assessment of Its Implementation on Technology Subjects. Stud Home Comm Sci, 3(2): 81-86.

[2] Egbochukwu, E. O (2008). Guidance and Counseling; A Comprehensive Text. Benin City. University of Benin Press.

[3] Olowu, A. A. (1991). Special Students in Normal Secondary Schools: Implication for Organisation for Economic Co-operation and Development (2000), Learning to Bridge the Digital Divide, OECD, Paris.

\section{CONCLUSION}


[4] Ifelunni, C. S. I (1997). Psychometric and Ethical Consideration in Counseling. Enugu: Auto-Century Publishing Company Limited.

[5] Afia, N. J. (2005). The Influence of Counselling Services on Educational Development of Secondary School Students in Awka-Ibom State. Journal of Counselling and Communication, 1 (2) (94-100).

[6] Nwaokolo, C. (2006). Appraisal of the Implementation off Guidance and Counseling Services at the Post-Primary level. Paper presented at the 2006 Annual Conference of Education.

[7] Zunker, V. G. (2002). Career Counseling: Applied Concepts of Life Planning 6th ed. U.S.A: Brooks/Cole.

[8] British Association for Counseling BAC, (1984). Code of Ethics and practice for Counsellors. Rugby: BAC

[9] Macleod, J. (2003). An Introduction to Counseling, 3rd edition. Maidenhead: open University Press.

[10] Akinboye, J. O. (1987). Guidance and Counselling Strategies for Handling Adolescent and Youth Problems. Ibadan: University press.

[11] Ofordile, L. (2002). The Adolescent: An Exposition. The Nigeria Journal of Education. 2(1) 123.

[12] Arua, A. U. (2006). Counseling the Gifted and Talented Children in Nigeria. Problem and Prospects. A paper presented at the (2006) conference off education at Nnamdi Azikiwe University Awka.

[13] Carew, P.F.C (1989). Introduction to Guidance Services, University of Maiduguri - a Lone-psychoeducational Services

[14] Ipage, B. (1983). Guidance and Counseling Practices Ill-Ife University of Ife Press.

[15] Olayinka, M.S (1985). Organizing the Guidance Services in Secondary Schools System. Nigerian Journal of Counseling and Development, Vol. 1 No 2, Pg 1-3.

[16] Bandele, S. O. (Ed.). (2006). Development of modern ICT and internet system. Abuja, Nigeria: Panof Press.

[17] Jimoh, A. T. (2007). Students' attitude towards ICT in Nigeria tertiary institutions. Education Focus, 1(1), 73-79.

[18] Ofodu, G. O. (2007). Nigeria literacy educators and their technological needs in a digital age. Education Focus, 1(1), 22-30.

[19] Oladimi, B. \& Oladipo, T. (2006). Information and technology in schools: the way forward. . (1st ed.). Ibadan: Bounty Press Limited.

[20] Bolaji, L. (2007). ICT the hopes and the reality in schools. (1st ed.).Ibadan: University Press.

[21] Kelly, T. (2004). Learning with I.C.T in schools. . (3rd ed.).UYO: Abaam Publishing. Lee, C. (2000), Cybercounseling and empowerment: bridging the digital divide", in Bloom, J.W. \& Walz, G.R. (eds.), Cybercounseling and Cyberlearning: Strategies and Resources for the Millennium, pp.85-93, American Counseling Association/CAPS, Alexandria, VA.
[22] Tookiji, C. (2007). Improving ICT knowledge through counselling the child: A hand book. . (3rd ed.).New York: Free Press.

[23] Palmer, B. (2007). The use of computer technology in university teaching and learning: A critical perspective. (4th ed.).San Francisco: Josey- Bass Publishers.

[24] Chun - Chun (2001). Students' perception of ICT related support in counselling placements. Journal of psychological Studies 2,147-151.

[25] Phrema, K. (2006). Integrating ICT in the classroom. (3rd ed.).Cambridge MA: Harvard Business School Press.

[26] Green, R. \& Yallow, R. (2002). Technology and its impact in classroom. (2nd ed.). New York: Cambridge University Press

[27] Anyamene, A. N., Nwokolo, C. N. \& Anyachebelu F.E.(2010).Information technology as a gateway for effective counselling. A paper presented at annual conference of the Faculty of Education, Nnamdi Azikiwe Univeristy, Awka, 30 th - 3rd September, 2010.

[28] Offer, M. \& Sampson, J.P. (1999), "Quality in the content and use of information and communications technology in guidance", British Journal of Guidance and Counselling, Vol.27 No.4, pp.501516.

[29] Offer, M., Sampson, J.P. \& Watts, A.G. (2001), Technology and the Future: Strategic Implications for Higher Education Careers Services of Technically Mediated Service Delivery, Higher Education Careers Services Unit, and Manchester (in press).

[30] Watts, A.G. \& Dent, G. (2002), “'Let your fingers do the walking': the use of telephone helplines in career information and guidance", British Journal of Guidance and Counselling, Vol.30 No.1 (in press).

[31] Shiran, R. (2001). I.C.T in counselling. (1st ed.).London: Routledge,

[32] Martin, P. (1998). Transforming School Counseling. Unpublished mansucript. Washington, DC: The Education Trust.

\section{AUTHORS - BIBLIOGRAPHY}

Oye N. D., receive his M.Tech OR (Operations Research) degree from the Federal University of Technology YolaNigeria in 2002. He is a lecturer in the department of Mathematics and Computer Science in the same University (for the past 15yrs). At the moment he is a $\mathrm{PhD}$ student in the department of Information Systems in the Faculty of computer Science and Infor-mation systems at the Univeristi Teknologi Malaysia, Skudai, Johor, Malaysia.

Obi M.C, had her M.Ed (Guidance and counseling) degree from Universiti of Technologi Malaysia in 2011.Presently, she is a PhD student also in Guidance and counseling in the Faculty of Education at the same 
university. Universiti of Technologi Malaysia, skudai, Johor, Malaysia.

Prof Dr. Tajudin Bin Ninggal, obtained B.Ed(Hons) Counseling (UPM); MA (Counseling Psychology) Ed. D (Counseling \& Supervision) ( Western Michigan) L.P.C. I am professionally trained in counseling psychology with emphasis in student affairs and development, individual and group dynamics, career development, multicultural counseling, stress management and psychological profiling. As an educator and a Licensed Professional Counselor, I have worked closely with diverse population ranging from young adults, university students, parents, professionals and international population.

Bernice Amos received her B.Ed degree in Guidance and counseling at the federal University of Technology YolaNigeria. She is a tutor in Gwadabawa Senior Secondary School Yola- Nigeria. 